\title{
Research on the Role of Modern Mentoring System in Promoting the Transformation and Development of Cuisine Major
}

\author{
Lin Li \\ Jilin Agricultural Science and Technology university, Jilin 132101, China \\ email: ziyul11@sina.com,
}

Keywords: Modern mentoring system, transformation and development, culinary arts

\begin{abstract}
In order to adapt to the modern education, the traditional apprenticeship has evolved into a "modern apprenticeship", although the word, its emphasis on "cooperation", "dual culture", "Alternation", "job" is the core content to meet the needs of contemporary professional transformation and development. The exploration of modern apprenticeship system to promote the change and development of the role of professional cooking, we think it can improve teachers' ability of practice teaching, improving the practical ability, and shortening the distance between the school and the post is an important role in cultivating the spirit of bearing hardships good way.
\end{abstract}

\section{Introduction}

Traditional master view is a traditional view of mentoring on one Bangdai. The professor apprentice in the art is also used as a master of life, the work of assistant role, and the great relationship between employment and employment . In general, when the manual workshop in hand is not enough, it will recruit disciples and hiring young people, not only does it cultivates new generation of craftsmen, but it solves the manpower problems. Mentorship and emotional way, the employment relationship has become very stable, some mentorship can sustain life, the degree of stability is much higher than that of pure employment, so it be used on a large scale.

Currently , under the industrial production, premise of demand for talent is no longer a teaching problem that can be solved, modern education mode of batch culture can really solve the problem of quantity, but its quality has long been criticized, so that some enterprises have to spend a lot of manpower and material resources in new recruits. The resources to reculture, not only a waste of time, money, but also a waste of time for new employees. Against such a background, the modern apprenticeship system came into being. Its core is "cooperation", "dual culture", "Alternation", and "job"[1]. It has performance characteristics.

The depth integration of school and enterprises, students achieve joint training. The school cooperate with enterprises in the joint venture. The school is responsible for the teaching of basic knowledge, practice teaching in charge of the enterprises, both sides have to conduct training and management. [2] At the same time, the two sides should teach collaboration, namely teaching objectives should be consistent, teaching design to negotiate, teaching contents should be convergence, teaching methods and means should be diversified, teaching evaluation should be reasonable.

It puts forward higher requirements for the teachers. As a school teacher, or a business school "master" , in this kind of teaching mode, it puts forward higher requirements. [3] The school teachers only know the theory is far enough, but to be able to practice personally does not require comparable professional technicians and skilled operation. But at least for the enterprise of "master", only it is far enough, as the master, they know how to teach, how to understand the teaching design, teaching methods, teaching means, teaching language, and have enough teaching abilities. students role change. In this teaching background, not only do students at school, but also employees of the enterprise. [4] They must be do in accordance with the standards of enterprise employees strict demands on themselves in the enterprise."Doing" is the biggest characteristic of modern apprenticeship. The prominent advantage of internship is no longer the theory and practice will be separated, in the actual work is the validation of theoretical knowledge, but it is also for the lack of 
knowledge.

\section{The Difference and Relation between Traditional and Modern View of Master and Apprentice}

The traditional master and apprentice learning view can be a few years, also be several decades. The key lies is whether the master's apprentice [5]. Modern apprentice can be recognized in a difference of the concept of the educational system , maybe two years, three years, or four years, the same with the school system, compared with the traditional concept of apprenticeship, the learning period is short..

Traditional view on mentoring is one-on-one training, pay attention to relationships. The master is the hand of pure teaching apprentice, teaching practice can be said to be strictly "doing". But because the master knows little about teaching theory, not to mention the teaching design, teaching is mainly about thinking through experience and feeling. The modern view of the same "master and apprentice", and two or more "master apprentice", but is not a simple "two zone" mode, but in fact the "two zone" or "many to many" mode of modern society with mass production batch training requirements. "Master" need to delve into the teaching content, teaching theory, a scientific teaching design, and step by step.

In the traditional view, master senses are the evaluation standard, the standard by the master level of knowledge does not have great limitation, scientificity and applicability, it is not fair to the modern concept of master apprentice. Evaluation of both sides need to consult with a scientific and reasonable evaluation standard, the evaluation standard is required generally the applicability which not only is suitable for cooperative enterprises, but also other enterprises in the same applies, it is suitable for students to learn the scientific feedback and comprehensive evaluation.

It has established a mentoring relationship. Both traditional and modern master view are required between master and apprentice which has established the feelings of the mentoring relationship, no reservations to the master, at apprentice school, apprentice to master to respect such as teachers, as a father, and this is also a part of the personality education. it emphasizes the important role of practice. Both the pure "learning by doing" in the traditional concept of apprenticeship, and the "learning by doing" in the modern apprenticeship theory have emphasized the important role of practice .

\section{The Role of Modern Mentoring System in Promoting the Transformation and Development of Cuisine Specialty}

It improves teachers' practical teaching ability. The modern apprenticeship is the practice teaching ability for teachers to a great challenge. When the students' practice ability is more than teachers who are only holding books to teach, this teacher will not get students to recognize and respect the dignity . Teachers will be a great challenge, teachers' prestige will also collapse, so although the "school enterprise cooperation", "combination" and "double teaching". At the same time, the school also requires not only theory teachers have strong practical ability, practical teaching ability also to have the extremely high, set a good example of learning to the students, set up the good teacher's prestige. It is the basic requirement in teaching work in the new period.

It improves practical ability ."Modern apprenticeship teaching", more emphasis on fostering practical ability, "cooperation", "dual culture", "Alternation" and "job", whatever the points are more emphasis on learning in practice, especially in the process of internship, students are not only passive absorption of knowledge, but also the practitioners and product knowledge creators, the talents, the biggest characteristic is to abandon away the rich theoretical knowledge and practical ability is poor or no defects.

It will be shorten the distance between students studies and jobs [6].Our education is the talents that society needs, the school will set up the relevant professional which is consistent with the rules of social development, but because the school personnel training takes time, from freshmen to graduation, at least three years, and for the rapid development of now society, three years means 
great changes, not to mention the average undergraduate course of four years.

Modern apprenticeship has advocated "doing" learning in practical work by the employer directly students ,not only can improve the ability of practice, but also will be able to learn knowledge into productivity as soon as possible, greatly shorten the distance between the school and the post, not only save enterprises in the cost, but also saves the cost of learning of students.

Recently, the Internet has a word called "rich two generations", although I disagree, but we can't deny that with the improvement of living standards, the basic conditions of the contemporary college students' family are very good, in the home are mostly spoiled grew up and generally don't have hard-working spirit.

A common example, in recent years, originally very normal but clean laboratories health become more and more difficult . The task is done by the teacher and the students left behind, then it becomes the teacher took the students to work together, the teacher asked students to do . Even evolved into a clean laboratory health becomes bonus conditions. Even so, throughout the oil cooking the laboratory is still difficult to clean completely. Teachers complain that students to do more quickly and more thoroughly than they do . And not because students are basically clean.

In the school, when students and teachers talk, the teacher can also indulge students can practice in the enterprise field, grassroots labor is the problem students have to first face ,it is also the biggest problem in the enterprise, they are employees, work is work, no conditions of space and reason. One of the students came back from the internship and said, now I see anywhere is not clean, the first thing is clean, has become a reflex. In the "hardship", the actual working environment of enterprises, "master" words can be much more useful than the words of school teachers, it can be seen that modern mentoring is indeed a good way to cultivate the spirit of hardship .

It is the needs for professional transformation and development . For professional cooking and nutrition education, the knowledge content is broad rather than deep, from the point of view of occupation development, it is a practical application ability rather than studying advanced theory. It is a comprehensive professional, a very strong applied for the professional, professional. The direction of development should focus on practical application rather than theoretical research. The depth of more than ten years of teaching practice tells us to pay attention to theoretical professional cooking practice despise road gets narrower .No enterprise will accept only a textbook and not cook, no cook will accept a teacher who cannot cooking. It is the basic mode professional culinary apprenticeship , and more professional cooking with the life of the indissoluble bound that pay attention to practice, pay attention to the core competence and teaching mode of professional development coincides with the intention of cooking, so the modern apprenticeship teaching mode, and it is necessary for this major transformation and development.

It is the necessary requirement of social development . Transformation of development in Colleges and universities at present, transformation and development has been a foregone conclusion, it is the requirement of the whole society and the employer's requirements, the talent itself and the development of breaking the requirements, it has become the consensus of higher education, but the transformation of the way how to choose, as a difficult problem in front of educational reformers. Transformation plays an important role in cultivating talents, students are not mice, can not be used to do the experiment . Although the current transformation of the concept of teaching seriously, can also meet the students' interests, corporate interests and the interests of the school is less and less.

Modern apprenticeship is undoubtedly the best choice in line with the interests of three parties, which has a long history, has experienced the test of practice; it emphasizes the three party cooperation to the maximum extent possible to protect the interests of the three parties; the requirement of "doing". Not only lies in the emphasis on practical, but also emphasizes the important role of the theory of knowledge. Therefore, modern mentoring is the inevitable requirement of the social development.

While advocating the functions of the modern mentoring system, we should also be conscious of the fact that there are still some deficiencies in it. Only by realizing these problems can we avoid 
mistakes effectively and improve their application effects. Enterprise requires in-depth cooperation. The modern apprenticeship requirements of school enterprise cooperation, such cooperation is not based on simple labor and employment level, but to the enterprise and puts forward the talent training scheme, provide practice "master", combined with the school student management, personnel training, to consider the issue more than start from the perspective of the interests of the enterprise.

Students are not cheap workers. Establishing the correct view of students is the goal of enterprise learning, enterprises avoid take students as cheap labor concept, more supervision of enterprises to let the students really learn knowledge, more than machine. A line machines has many different types of students to study or to cultivate comprehensive ability, so to avoid a single long engaged in mechanical work, one that can only exercise the students' practice ability, comprehensive ability cultivation is impossible.

\section{Conclusion}

It guides unique preexistence for modern apprenticeship and the traditional concept of mentoring .It has difference and inheritance, teaching mode from the traditional concept of mentoring cooking out bound to return to the modern apprenticeship, it is an inevitable requirement of cooking professional development, is the inevitable requirement of social development. The modern apprenticeship for cooking professional development is huge and a magic weapon for the transformation and development of professional cooking, although it has its own inherent defects, but it can be avoided, for the school, the modern apprenticeship means cannot rely on enterprises, enterprises involved in the process of laissez faire, schools in depth, their inherent defects can be obtained effective remedy.

\section{Acknowledgements}

In this paper ,the research by Jilin Education Department, 2016, key research topic of vocational education and adult education reform, project approval number: 2016ZCZ017: Modern mentoring system construction to promote the development of applied cuisine specialty.

\section{Reference}

[1] Li Jiangli. Research on the "four modernizations" training mode of modern mentoring system in Vocational Education [J]. economist. 2013(2)

[2] Cheng Jie. The modern apprenticeship pilot elements and school practice model [J]. Jie. Vocational Education Forum. 2015 (21)

[3] Wang Peng, Wu Shuan, Li Songliang. Discussion on the construction of vocational education talent training model under the framework of modern apprenticeship system [J]. vocational and technical education. 2015 (20)

[4] Li Li. Integrated application of mentoring system based on work study combination. [J]. Vocational Education Forum,.2010(4)

[5] He Jialin. Modern apprenticeship in the campus to explore [J]. Vocational Education Forum,2015 (1)

[6] Jia Cuiju, Shang and Gong. The advantages of introducing modern master and apprentice system into the basic accounting course teaching [J]. new campus (early). 2016 (11) 